\title{
SIMULASI FLEXSIM UNTUK OPTIMASI SISTEM ANTRIAN POLI UMUM RAWAT JALAN RUMAH SAKIT X
}

\author{
Nunung Nurhasanah, Siti Nurlina dan Tri Nugroho \\ Teknik Industri, Fakultas Sains dan Teknologi,Universitas Al Azhar Indonesia \\ Jl. Sisingamangaraja, Kebayoran Baru, Jakarta Selatan 12110 \\ e-mail: nunungnurhasanah@uai.ac.id
}

\begin{abstract}
ABSTRAK
Kualitas suatu rumah sakit selain ditentukan oleh tingkat keahlian dokter yang dimiliki, sarana dan prasarana pendukung yang berkualitas juga ditentukan oleh sistem antrian yang terjadi di dalam rumah sakit tersebut. Jika tingkat kedatangan dan tingkat pelayanan yang diberikan kepada pasien tidak seimbang akan menyebabkan ketidakpuasaan bagi pasien dan kerugian bagi rumah sakit karena pasien cenderung beralih ke rumah sakit yang memiliki tingkat pelayanan yang lebih optimal. Pada penelitian ini, simulasi dilakukan khusus pada sistem antrian Dokter Poli Umum rawat jalan. Pada penelitian ini dinyatakan bahwa semua pasien yang datang melakukan layanan mulai dari registrasi hingga pengambilan obat ke apotek RSX. Tujuan umum dari penelitian adalah meningkatkan kualitas pelayanan di poli umum rawat jalan RSX. Tujuan khusus dari penelitian ini adalah: (1) menentukan jumlah optimum pasien yang dapat dilayani oleh dokter umum di antrian poli umum, dan (2) lamanya waktu tunggu yang harus dilalui pasien pada antrian rawat jalan di RSX berdasarkan software Flexsim. Jumlah optimum pasien yang dapat dilayani dalam 1 hari adalah 16 pasien, dengan kondisi 1 orang pasien tidak dapat terlayani. Oleh sebab itu, dinyatakan bahwa terdapat 17 pasien yang masuk dalam sistem antrian poli umum rawat jalan. Sistem antrian yang terjadi adalah pasien masuk dalam sistem antrian diawali di bagian registrasi, ruang tunggu dokter, dilayani dokter umum, apotek, ruang tunggu, menerima obat dan meninggalkan sistem antrian. Lamanya waktu tunggu untuk sistem antrian ini adalah 107,18 menit atau selama 1,78 jam.
\end{abstract}

Kata Kunci: Sistem Antrian, Waktu Menunggu, Simulasi

\begin{abstract}
The quality of a hospital other than determined by the level of expertise of the doctor-owned, facilities and infrastructure, quality is also determined by the queuing system that occur in the hospital. If the arrival rate and the level of service provided to the patient is not balanced will lead to patient dissatisfaction and loss for the hospital because patients tend to switch to a hospital that has a more optimal level of service. In this research, simulations done specifically on the system queue Public Poli outpatient doctor. In this study stated that all patients who come to the service from registration to taking drugs to the pharmacy $R S X$. The general objective of the research is to improve the quality of care in general clinic outpatient RSX. The specific objectives of this study were: (1) determine the optimum number of patients that can be served by a general practitioner in the queue general clinic, and (2) the length of time patients wait to be passed in the queue outpatient RSX based software Flexsim. The optimum number of patients that can be served in one day was 16 patients, 1 patient with the condition can not be served. Therefore, it is stated that there are 17 patients were included in the general queue system poly outpatient. Queuing system that happens is the patient entered in the queuing system begins at the registration, doctor's waiting room, serviced general practitioners, pharmacy, waiting room, receiving medication and leave the queue system. The length of time waiting for this queuing system is 107.18 minutes or for 1.78 hours
\end{abstract}

Keywords: Queue System, Waiting Time, Simulation

\section{PENDAHULUAN}

Layanan merupakan indikator utama dalam keberhasilan usaha. Kualitas layanan industri jasa merupakan faktor utama yang harus diperhatikan dalam mempertahankan keberadaan dan persaingan industri jasa, tidak terkecuali industri jasa rumah sakit.
Rumah sakit merupakan industri jasa yang perkembangannya cukup pesat di Indonesia. Dirjen Bina Upaya Kesehatan Kemenkes Akmal Taher pada tahun 2014 menyatakan bahwa pertumbuhan industri jasa rumah sakit swasta adalah 5-10\% [1].

Data Kemenkes pada tahun 2014 menunjukkan bahwa jumlah rumah sakit swasta 
yang terdaftar per 1 Januari 2014 sebanyak 455 untuk rumah sakit umum dan 246 untuk rumah sakit khusus, rumah sakit swasta non profit sebanyak 531 dan rumah sakit khusus non profit berjumlah 202 [2].

Data Ikatan Dokter Indonesia menyatakan jumlah rumah sakit di Kota Depok dan sekitarnya adalah 16 rumah sakit. Terdiri dari 2 rumah sakit milik pemerintah dan 14 rumah sakit milik swasta [2].

Kualitas layanan di rumah sakit dapat mencakup berbagai aspek, seperti layanan antrian, layanan dokter dan konsultasi, layanan kebersihan, layanan kesediaan obat dan alat kesehatan. Layanan antrian merupakan salah satu layanan yang menjadi perhatian pasien. Oleh sebab itu, kualitas layanan terhadap sistem antrian di rumah sakit menjadi suatu hal yang menarik untuk diteliti.

Rumah Sakit X (RSX) merupakan salah satu rumah sakit ternama di kota Depok. RSX memiliki 21 poli yang aktif melayani pasien setiap hari.

Penelitian in dilakukan pada bagian rawat jalan, khususnya di poli umum. Poli umum merupakan poli yang ditangani oleh dokter umum yang memiliki tingkat kedatangan yang konstan setiap harinya. Rata-rata kedatangan dan pasien yang terlayani setiap bulannya adalah 335 pasien.

Penelitian ini mengukur tingkat optimalitas sistem antrian yang berlaku saat ini di RSX. Pengukuran dititikberatkan pada waktu layanan, jumlah pasien yang terlayani dan waktu tunggu pasien hingga terlayani dalam sistem antrian.

Hasil pengukuran tingkat optimalitas sistem antrian saat ini dibandingkan dengan usulan sistem antrian agar tingkat kepuasan pasien selaku pelanggan terpenuhi. Sistem antrian usulan diperoleh melalui pendekatan simulasi, dengan bantuan perangkat lunak Flexsim.

Pendekatan simulasi dipilih untuk memudahkan pemodelan dalam sistem antrian yang diusulkan. Simulasi merupakan salah satu cara yang dapat membantu dalam proses pengambilan keputusan. Percobaan dengan simulasi merupakan model yang mengadaptasi perilaku sistem nyata.
Simulasi pada penelitian ini dilakukan terhadap sistem antrian pasien pada layanan dokter umum di poli umum rawat jalan. Hasil simulasi diharapkan dapat membantu pihak manajemen rumah sakit dalam mengetahui tingkat performance karyawan dan dokter di rumah sakit. Selain itu, diharapkan dapat membantu pihak manajemen untuk mengambil strategi yang tepat dalam melakukan penambahan karyawan atau dokter yang sesuai dengan kondisi yang ada di rumah sakit.

Pada penelitian ini, simulasi dilakukan khusus pada sistem antrian Dokter Poli Umum rawat jalan. Pada penelitian ini dinyatakan bahwa semua pasien yang datang melakukan layanan mulai dari registrasi hingga pengambilan obat ke apotek RSX.

Tujuan umum dari penelitian adalah meningkatkan kualitas pelayanan di poli umum rawat jalan RSX. Tujuan khusus dari penelitian ini adalah: (1) menentukan jumlah optimum pasien yang dapat dilayani oleh dokter umum di antrian poli umum, dan (2) lamanya waktu tunggu yang harus dilalui pasien pada antrian rawat jalan di RSX berdasarkan software Flexsim.

\section{TINJAUAN PUSTAKA}

\section{Teori Antrian}

Antri (queue) merupakan kejadian yang biasa dalam kehidupan sehari-hari. Antrian tidak hanya dialami oleh manusia, tapi juga dialami adalah barang.

Kejadian antrian yang paling sering ditemui antara lain adalah menunggu di depan loket untuk mendapatkan tiket kereta api, menunggu pada SPBU, pada pintu jalan tol, ketika akan keluar dari supermarket, dan situasi-situasi yang lain merupakan kejadian yang sering ditemui. Tujuan penggunaan teori antrian adalah [3]

- Untuk merancang fasilitas pelayanan

- Untuk mengatasi permintaan pelayanan yang berfluktuasi secara random

- Untuk menjaga keseimbangan antara biaya (waktu menganggur) pelayanan dan biaya (waktu) yang diperlukan selama antri

Timbulnya antrian terutama tergantung dari sifat kedatangan dan proses pelayanan. 
Penentu antrian lain yang penting adalah disiplin antri. Disiplin antri adalah aturan keputusan yang menjelaskan cara melayani pengantri, misalnya, datang awal dilayani dulu, datang terakhir dilayani dulu, berdasar prioritas, dan secara random. Jika tak ada antrian berarti terdapat pelayan yang nganggur atau kelebihan fasilitas pelayanan

\section{Sistem Antrian}

Pelaku utama dalam sistem antrian adalah: (1) pelanggan (customer), dan (2) pelayan (server). Elemen dalam sistem antrian, yaitu: pelanggan (customer) dari suatu populasi (source) memasuki antrian (queue) untuk menerima layanan (service) dari fasilitas layanan (service facility) [3].

Kerangka dalam sistem antrian adalah kedatangan pelanggan untuk mendapatkan layanan, pelanggan menunggu untuk mendapatkan layanan, pelanggan mendapat layanan, dan pelanggan meninggalkan sistem antrian. Gambar 1 menyajikan kerangka sistem antrian.

\section{Simulasi}

Simulasi merupakan suatu aktivitas meniru perilaku dari sistem nyata. Dari tiruan itu, dipelajari berbagai hal yang ada dalam sistem nyata sehingga diperoleh informasi tentang sistem nyata. Peniruan sistem nyata dilakukan dengan mengembangkan dalam bentuk program komputer.

Simulasi komputer merupakan disiplin merancang model sistem fisik yang sebenarnya atau teoritis, melaksanakan model pada komputer digital, dan menganalisis output eksekusi.

Flexsim adalah aplikasi perangkat lunak simulasi berbasis PC digunakan untuk memodelkan, simulasi dan visualisasi proses bisnis. Flexsim dapat membantu menentukan kapasitas pabrik, menyeimbangkan lini manufakturing, mengatur penyebab penundaan, memecahkan masalah inventori, menguji praktek penjadwalan baru, dan mengoptimumkan laju produksi. Setiap model Flexsim dapat digambarkan dalam animasi realitas virtual 3D. Selain itu, Flexsim memungkinkan pemodel dengan kemampuan pemrograman model dan submode secara langsung dalam $\mathrm{C}++[4]$.

\section{METODE PENELITIAN}

\section{Penelitian Terdahulu}

Penelitian terdahulu yang pernah dilakukan menggunakan pendekatan simulasi dengan bantuan software Flexsim adalah penelitian yang dititikberatkan pada penjadwalan produksi di industri garmen.

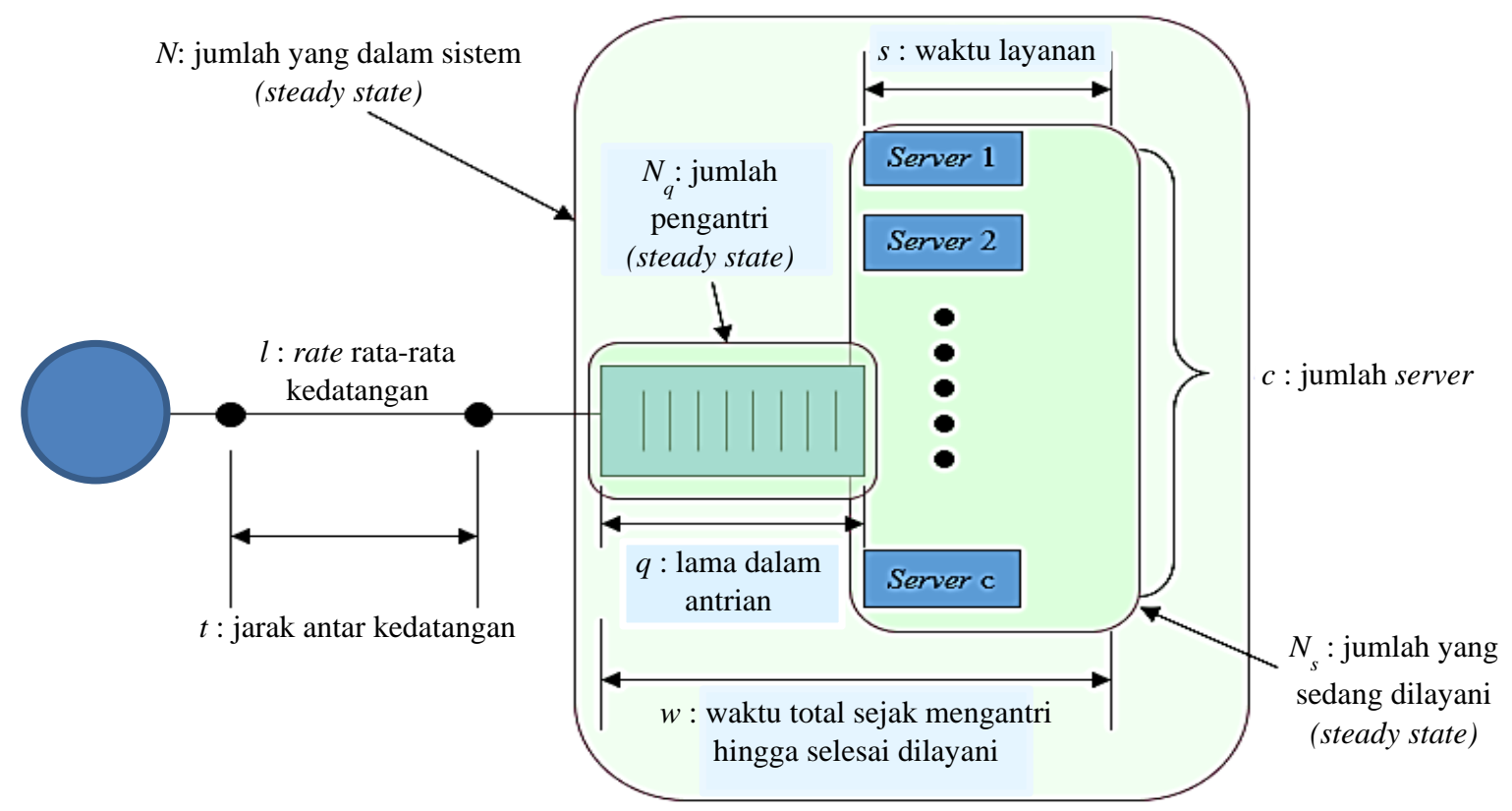

Gambar 1. Sistem Antrian [3] 
Pendekatan simulasi dengan bantuan software Flexsim pada penelitian tersebut dilakukan untuk memudahkan peneliti mendapatkan hasil optimal waktu produksi per unit per satuan waktu [4].

Untuk memperoleh waktu siklus yang akan dimasukkan dalam simulasi, maka terlebih dahulu harus menentukan waktu baku untuk seluruh stasiun kerja. Saat itu, terdapat 24 stasiun kerja yang harus diamati.

Penelitian tersebut menghasilkan waktu proses pembuatan produk selama 28 menit dengan mempertimbangkan jumlah mesin dan tenaga kerja yang tersedia.

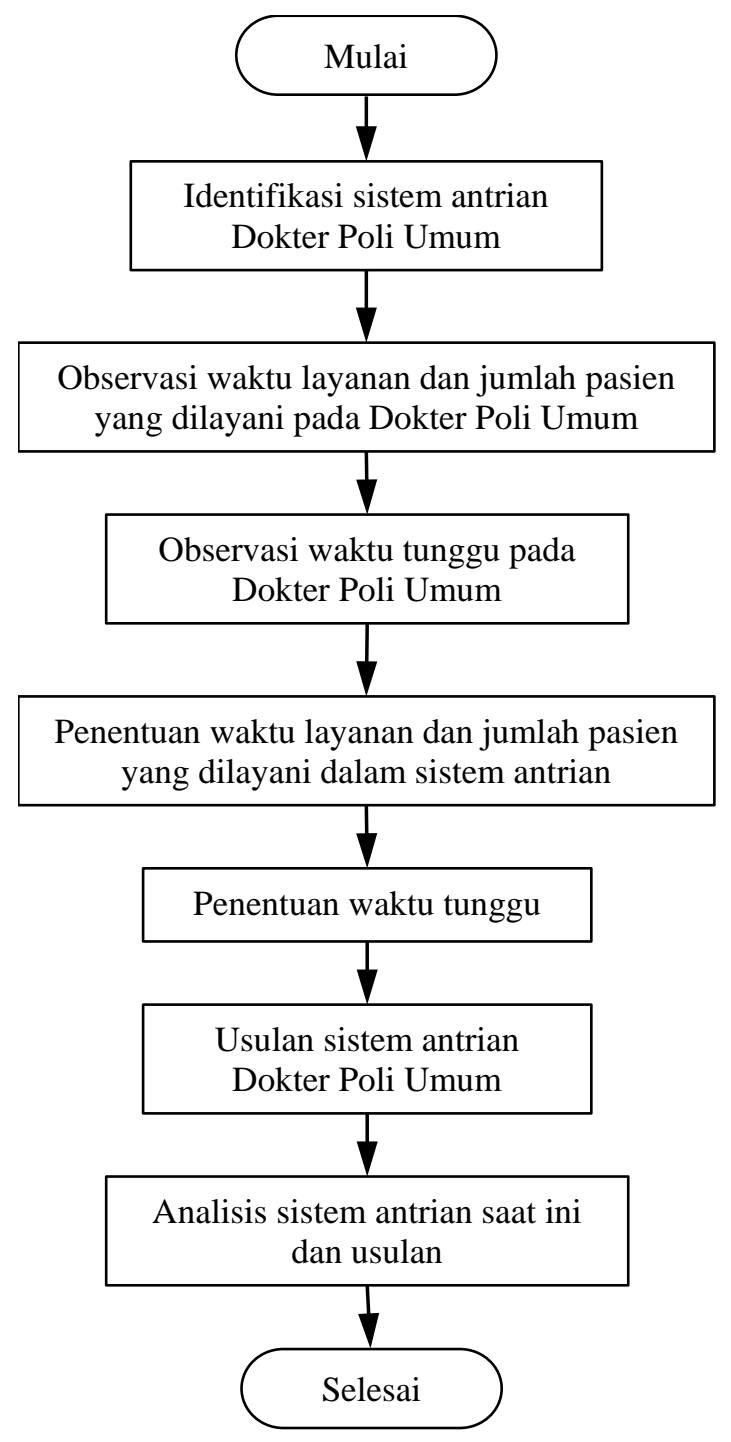

Gambar 2. Kerangka Berpikir

Penelitian ini diawali dengan identifikasi sistem antrian yang saat ini berlaku pada kegiatan dokter umum di Poli Umum pada
RSX. Penelitian dilanjutkan dengan melakukan observasi terhadap waktu layanan dan jumlah pasien yang dilayani, serta waktu tunggu yang terjadi di dokter poli umum.

Software Flexsim merupakan alat bantu yang digunakan untuk menentukan waktu layanan dan jumlah pasien yang dilayani, serta waktu tunggu dalam sistem antrian dokter poli umum.

Setelah kondisi awal teridentifikasi dan kondisi usulan berdasarkan software Flexsim dilakukan, maka dilakukan analisis untuk menentukan sejauh mana hasil simulasi ini memungkinkan untuk diimplementasikan di RSX. Gambar 2 menyajikan kerangka berpikir dalam penelitian ini.

\section{HASIL DAN PEMBAHASAN}

RSX saat ini memiliki 21 layanan poli rawat jalan. Empat poli yang memiliki tingkat kedatangan konstan tiap bulan dan lebih dari 200 kedatangan tiap bulan adalah: (1) Poli anak, (2) poli obgin, (3) poli gigi, dan (4) poli umum. Tabel 1. menyajikan data kedatangan pasien selama 1 tahun untuk poli umum.

Tabel 1. Jumlah Kedatangan Pasien Poli Umum Rawat Jalan Tahun 2013

\begin{tabular}{cccc}
\hline Bulan & $\begin{array}{c}\text { Jumlah } \\
\text { Pasien } \\
\text { (orang) }\end{array}$ & Bulan & $\begin{array}{c}\text { Jumlah } \\
\text { Pasien } \\
\text { (orang) }\end{array}$ \\
\hline Januari & 275 & Juli & 341 \\
Februari & 315 & Agustus & 316 \\
Maret & 312 & September & 312 \\
April & 347 & Oktober & 346 \\
Mei & 390 & November & 354 \\
Juni & 305 & Desember & 396 \\
\hline
\end{tabular}

Hasil observasi dan interview dengan pihak menajamen, diketahui bahwa saat ini diperkirakan dalam satu jam seorang dokter umum dapat melayani 4 hingga 6 pasien. Gambar 3 menyajikan sistem antrian dokter umum di poli umum rawat jalan RSX.

Sistem antrian yang terjadi di sini adalah:

1. Terjadi kedatangan pasien untuk siap masuk dalam sistem antrian di meja registrasi, yang akan diterima oleh petugas administrasi. Kegiatan yang terjadi adalah pasien mendaftarkan nama dan kepemilikan 


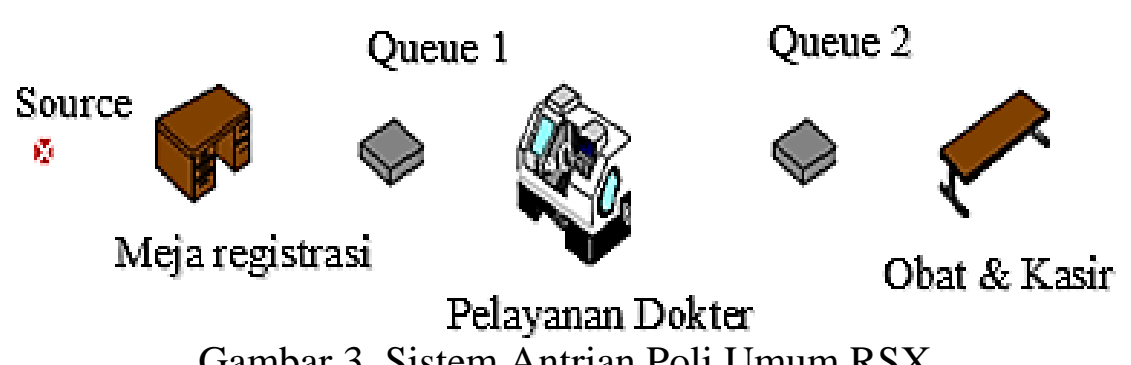

Gambar 3. Sistem Antrian Poli Umum RSX

asuransi. Petugas akan mencatat rekam medik pasien, jika pasien adalah pasien yang pernah terdaftar, dan membuat status rekam medik baru karena pasien adalah pasien yang pertama kali terdaftar di RSX. Petugas juga akan mencatat poli dan dokter yang dipilih pasien akan dikunjungi.

2. Pasien sudah masuk dalam sistem antrian, dan berada pada ruang tunggu poli umum. Pasien menunggu untuk dilayani oleh dokter umum.

3. Pasien masuk dalam pelayanan dokter. Pasien akan diterima oleh dokter untuk mengkonsultasikan keluhannya. Kemudian pasien akan ditindak oleh perawat, untuk ditimbang, diukur tinggi, diukur suhu dan diukur tekanan darah. Setelah itu, konsultasi kembali dilakukan, dan dokter akan memberikan resep, serta penjelasan untuk penggunaan resep bagi pasien.

4. Setelah pasien dilayani dokter, maka pasien akan masuk dalam antrian pembelian obat di apotek. Pada pos ini, pasien akan menunggu
5. Pasien akan dilayani untuk pembayaran dan pengambilan obat sesuai resep.

Tampilan dalam Flexsim untuk sistem antrian dokter umum di poli umum rawat jalan RSX disajikan pada Gambar 4.

Adapun input data yang dimasukan kedalam entities terdiri dari waktu proses atau siklus setiap stasiun (dalam hal ini pos layanan) dan waktu operasional pelayanan dokter dalam sehari. Pada penelitian ini waktu proses atau pelayanan setiap stasiun kerja secara detail disajikan pada Tabel 2.

Tabel 2. DataWaktu Pelayanan

\begin{tabular}{clc}
\hline No & \multicolumn{1}{c}{ Kegiatan } & $\begin{array}{c}\text { Waktu Layanan Rata- } \\
\text { rata (menit) }\end{array}$ \\
\hline 1 & Tunggu registrasi & 13,16 \\
2 & Registrasi & 21,9 \\
3 & Ruang Tunggu 1 & 8,8 \\
4 & Dokter Umum & 19,1 \\
5 & Ruang Tunggu 2 & 17,4 \\
6 & Obat dan Kasir & 16,1 \\
\hline
\end{tabular}

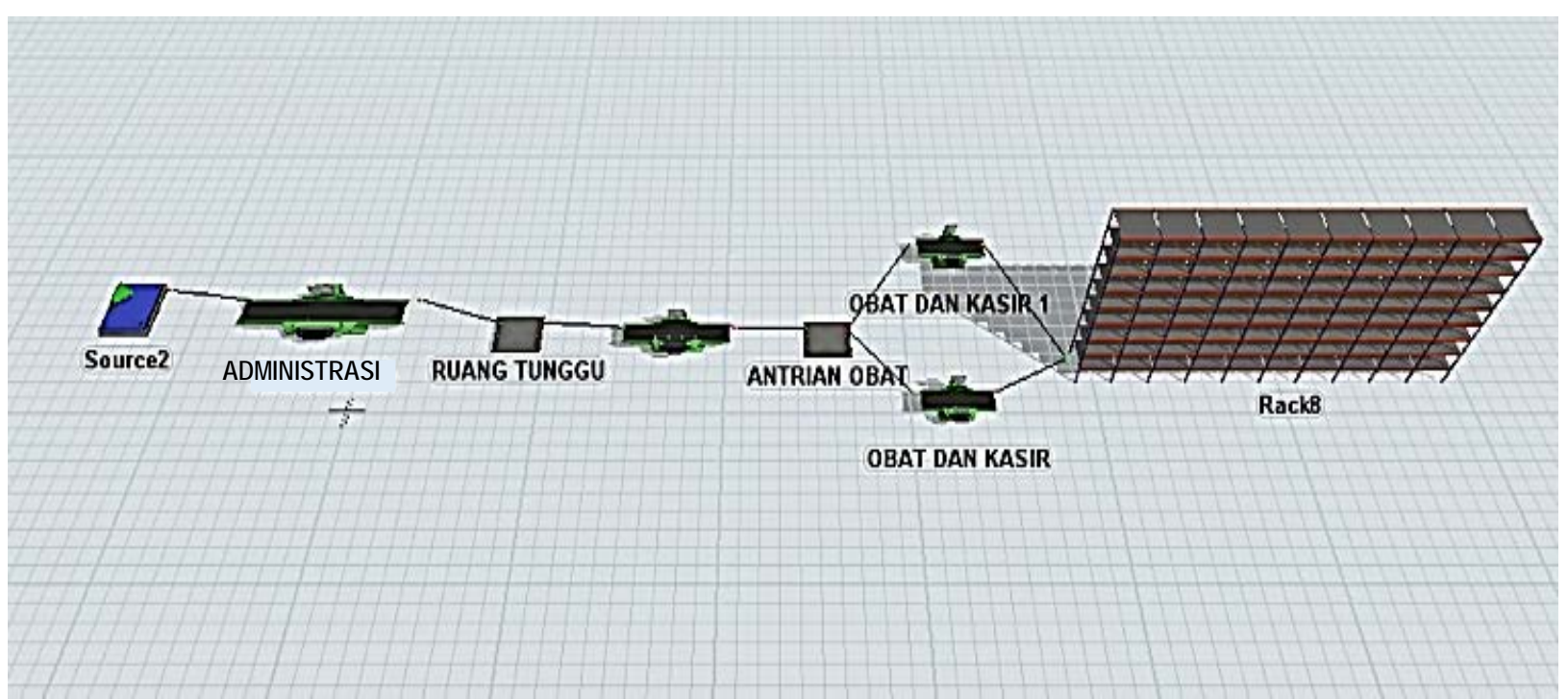

Gambar 4. Sistem Antrian dalam Flexsim 
Tabel 3. Hasil Simulasi Sistem Antrian dengan Flexsim

\begin{tabular}{llrrrrr}
\hline \multicolumn{1}{c}{ Object } & Class & $\begin{array}{c}\text { Stats_ } \\
\text { content }\end{array}$ & $\begin{array}{c}\text { stats_ } \\
\text { contentmin }\end{array}$ & $\begin{array}{c}\text { stats_ } \\
\text { contentmax }\end{array}$ & $\begin{array}{c}\text { stats_ } \\
\text { contentavg }\end{array}$ & stats_input \\
\hline Source2 & Source & 0 & 0 & 1 & 1 & 0 \\
Administrasi & Processor & 0 & 0 & 1 & 0,591274 & 35 \\
Ruang Tunggu & Queue & 17 & 0 & 17 & 8,963441 & 35 \\
Dokter Umum & Processor & 1 & 0 & 1 & 0,929851 & 18 \\
Antrian Obat & Queue & 1 & 0 & 1 & 0,755814 & 17 \\
Obat \& Kasir 1 & Processor & 0 & 0 & 1 & 0,377052 & 5 \\
Rack8 & Rack & 16 & 1 & 16 & 6,297482 & 16 \\
Obat \& Kasir & Processor & 0 & 0 & 1 & 0,524790 & 11 \\
\hline
\end{tabular}

Tabel 4. Hasil Simulasi Sistem Antrian dengan Flexsim Lanjutan

\begin{tabular}{llrrrrrr}
\hline \multicolumn{1}{c}{ Object } & Class & $\begin{array}{c}\text { stats_- } \\
\text { output }\end{array}$ & $\begin{array}{c}\text { stats_ } \\
\text { staytime } \\
\text { in }\end{array}$ & $\begin{array}{c}\text { stats_ } \\
\text { staytimemax }\end{array}$ & $\begin{array}{c}\text { stats_ } \\
\text { staytime } \\
\text { avg }\end{array}$ & $\begin{array}{c}\text { state } \\
\text { curre } \\
\text { nt }\end{array}$ & state_since \\
\hline Source2 & Source & 35 & 0 & 6,778544 & 1,448102 & 5 & 407,35920 \\
Administrasi & Processor & 35 & 7 & 7 & 7 & 1 & 414,35920 \\
Ruang Tunggu & Queue & 18 & 10 & 215,237671 & 107,189189 & 8 & 414,35920 \\
Dokter Umum & Processor & 17 & 22 & 22 & 22 & 2 & 407,21514 \\
Antrian Obat & Queue & 16 & 19 & 19 & 19 & 7 & 402,21514 \\
Obat \& Kasir 1 & Processor & 5 & 20 & 20 & 20 & 1 & 265,21514 \\
Rack8 & Rack & 0 & 0 & 0 & 0 & 1 & 0 \\
Obat \& Kasir & Processor & 11 & 20 & 20 & 20 & 1 & 419,21514 \\
\hline
\end{tabular}

Pada pos registrasi, diidentifikasi waktu setup adalah 3 menit dan waktu proses selama 4 menit. Pada pos ini ditetapkan maksimum waktu menunggu adalah 10 menit.

Pada pos pelayanan dokter umum, diidentifikasi waktu setup adalah 5 menit, dan waktu proses selama 17 menit. Pada pos ini ditetapkan maksimum waktu menunggu selama 19 menit.

Pada pos pelayanan obat dan kasir, diidentifikasi waktu setup selama 3 menit, dan waktu proses selama 17 menit. Pada ini ditetapkan maksimum waktu menunggu adalah selama 16 menit.

Hasil running simulation dengan Flexsim disajikan pada Tabel 3. Tabel ini menyatakan bahwa diketahui waktu maksimal dan minimal lamanya pasien mengantri dalam sistem. Pada Tabel 3 juga mengidentifikasi letak pos layanan atau lokasi terjadinya penumpukan pasien dalam mengantri untuk menunggu pelayanan.

Dengan jumlah dokter yang melayani hanya satu orang dan tingkat kedatangan pasien sebanyak 17 orang menyebabkan terjadinya penumpukan di ruang tunggu pasien sebelum mendapatkan pelayanan dari dokter,sehingga setiap pasien harus menunggu selama 107,18 menit atau selama 1,78 jam. Dari hasil simulasi tersebut dari 17 pasien yang datang yang dapat dilayani adalah sebanyak 16 pasien. Hanya 1 orang yang tidak terlayani.

\section{KESIMPULAN}

Jumlah optimum pasien yang dapat dilayani dalam 1 hari adalah 16 pasien, dengan kondisi 1 orang pasien tidak dapat terlayani. Oleh sebab itu, dinyatakan bahwa terdapat 17 pasien yang masuk dalam sistem antrian poli umum rawat jalan. Sistem antrian yang terjadi adalah pasien masuk dalam sistem antrian diawali di bagian registrasi, ruang tunggu dokter, dilayani dokter umum, apotek, ruang tunggu, menerima obat dan meninggalkan sistem antrian. Lamanya waktu tunggu untuk sistem antrian ini adalah 107,18 menit atau selama 1,78 jam.

\section{DAFTAR PUSTAKA}

[1]. Jumlah Rumah Sakit Umum Diprediksi Tumbuh 10\% Tahun Depan, http://industri.bisnis.com/read/20140914/ 12/257255/ jumlah- rumah- sakit- umumdiprediksi-tumbuh-10-tahun-depan, (12 Februari 2015).

[2]. Daftar Rumah Sakit di Kota Depok, http://idi-depok.blogspot.com/2012/05/ 
daftar-rumah-sakit-di-kota-depok.html (12 Februari 2015).

[3]. Hamdy A. Taha. (1996). Riset Operasi edisi kelima (terjemahan), Jilid 2. Jakarta: Binarupa Aksara.

[4]. Nurhasanah, Nunung., dkk. (2014). Penjadwalan Produksi Industri Garmen dengan Simulasi Fleksim. Jurnal Ilmiah Teknik Industri, Universitas Tarumanagara. Volume 2 nomor 3, Oktober 2014.p:141-148. 